\title{
AN EVALUATION OF RESIDENTIAL CARE FOR TETRAPLEGICS
}

\author{
By Barbara Richards, Dip.Soc.Sc., A.I.M.S.W. \\ National Spinal Injuries Centre, Stoke Mandeville Hospital, Aylesbury, England
}

Abstract. A total of 280 tetraplegics admitted to the National Spinal Injuries Centre between 1970-75 were followed up. Sixty-five cases found to require residential care were examined.

Key words: Tetraplegics; Residential care.

ONE of the most complex problems facing the medical social worker is that of the long-term care of patients who, following spinal cord injury, cannot for a variety of reasons go home on discharge from hospital. Almost without exception these are tetraplegics. Most patients accept long-term care in institutions unwillingly but because so often it is inevitable whether on a temporary or permanent basis they face the prospect with resignation. Unfortunately, they face it at a time when usually they are least able to cope and have not fully accepted their disability. What are the choices and how does the medical social worker select a residential establishment to suit a particular person?

Each county in the British Isles varies in the residential facilities it has to offer the young and geriatric physically handicapped. These facilities may be provided by statutory or voluntary organisations or by private enterprise. On the whole the number of residential units for the disabled are being expanded but some counties as yet have no suitable provision for the young chronic sick at all. Selection is limited by financial aspects, distribution of Homes and by available vacancies. There may be a considerable waiting time before admission, sometimes up to 2 years, as so often it is a question of stepping into 'dead men's shoes'. Tetraplegics who have to accept residential care often have scanty knowledge of what they are going to, are treated as packages, sent away and forgotten.

I wanted to know what had happened to them and it seemed important to find out two things: ( $a$ ) what is the aim of residential establishments ? $(b)$ what is the patient seeking? For this purpose I followed up 280 tetraplegics, both complete and incomplete, with whom I worked between I970-75 inclusive.

Table I shows that approximately 30 per cent were unable to be discharged home. Of this 84, 26 went back to their referring hospitals. Results are shown in Table II.

Seven died and I7, after varying lengths of time, went home; the remaining two, one male and one female, went to voluntary-run units. With 26 excluded, this left a total of 58 for whom admission was arranged to various establishments. The remaining 196 tetraplegics were followed up by letter, phone or personal interview to discover whether, for any reason, they have been compelled to accept residential care following discharge home. I obtained details from I 46 patients. Results are shown in Table III, and from this you will see that only five, all men, were subsequently admitted to long-term care. 
PAPERS READ AT THE ANNUAL SCIENTIFIC MEETING, I 977

TABLE I

Two hundred and eighty tetraplegics admitted 1970-75 inclusive

Year Men Women Children Total Number

to go home

\begin{tabular}{lrrrrr}
\hline I970 & 28 & I6 & 4 & 48 & I4 \\
I97I & 36 & I5 & I & 52 & 23 \\
I972 & 28 & I5 & I & 44 & I I \\
I973 & 33 & I0 & 3 & 46 & 8 \\
I974 & 30 & 9 & 7 & 46 & I3 \\
I975 & 28 & I I & 5 & 44 & I5 \\
Total & I83 & 76 & 2 I & 280 & 84 \\
\hline
\end{tabular}

TABLE II

Twenty-six tetraplegics returned to referring hospital

\begin{tabular}{|c|c|c|c|c|c|c|c|}
\hline \multirow[t]{2}{*}{ Year } & \multicolumn{3}{|c|}{$\begin{array}{c}\text { Subsequently sent } \\
\text { home or to Y.D.U. }\end{array}$} & \multicolumn{3}{|c|}{$\begin{array}{l}\text { Died in referring } \\
\text { hospital }\end{array}$} & \multirow[t]{2}{*}{ Tota } \\
\hline & $\overline{\text { Men }}$ & Women & Children & $\overline{M e n}$ & Women & Children & \\
\hline I970 & & I & & 2 & & & 3 \\
\hline 1970 & 5 & 2 & & I & & & 8 \\
\hline I972 & & 2 & & I & I & & 4 \\
\hline I973 & & I & & & I & & 2 \\
\hline I974 & 3 & 2 & & & & & 5 \\
\hline 1975 & 2 & I & & & & I & 4 \\
\hline Total & IO & 9 & & 4 & 2 & I & 26 \\
\hline
\end{tabular}

TABLE III

One hundred and forty-six tetraplegics discharged home

\begin{tabular}{|c|c|c|c|c|c|c|c|}
\hline \multirow[t]{2}{*}{ Year } & \multirow{2}{*}{$\begin{array}{l}\text { Admission } \\
\text { to } \\
\text { residential } \\
\text { care } \\
\text { (men) }\end{array}$} & \multicolumn{2}{|c|}{ Died } & \multicolumn{3}{|c|}{ Still at home } & \multirow[t]{2}{*}{ Total } \\
\hline & & Men & Women & Men & Women & Children & \\
\hline I970 & & 3 & & 13 & 6 & 2 & 24 \\
\hline I97I & 2 & 2 & 2 & 18 & I & & 25 \\
\hline I972 & I & I & & 15 & 6 & & 23 \\
\hline I973 & I & 2 & I & 18 & 4 & 3 & 29 \\
\hline I974 & I & & & I6 & 4 & 4 & 25 \\
\hline I975 & & 2 & & 12 & 5 & I & 20 \\
\hline Total & 5 & IO & 3 & 92 & 26 & IO & I46 \\
\hline
\end{tabular}


Sixty-five tetraplegics in residential care were finally followed up. Table IV shows you in which type of institution they were allocated places. Table V shows you how they have progressed.

1970

Out of the six who went to statutory homes, three men, all complete $\mathrm{C}_{5}$ lesions, died. One of the ladies, also a complete $\mathrm{C}_{5}$, died after 4 months but the other female, $\mathrm{C}_{5} / 6$ lesion, was resettled in the community after 4 years and is even now at university learning to be a social worker. Out of the three who went to geriatric units, one female survived for 4 months, one male only I month and the remaining man, an incomplete $\mathrm{C}_{4}$ lesion. after 2 years was allocated a flat and manages with the aid of full supporting services. The three ladies who went to voluntary homes continue to flourish.

\section{TABLE IV}

Sixty-five tetraplegics allocated places in institutions

\begin{tabular}{|c|c|c|c|c|c|c|c|c|c|c|}
\hline \multirow[t]{2}{*}{ Year } & \multicolumn{2}{|c|}{$\begin{array}{l}\text { Y.D.U. } \\
\text { statutory } \\
\text { Unit }\end{array}$} & \multicolumn{2}{|c|}{$\begin{array}{c}\text { Geriatric } \\
\text { unit }\end{array}$} & \multicolumn{2}{|c|}{$\begin{array}{c}\text { Cheshire Home } \\
\text { or other } \\
\text { voluntary } \\
\text { association }\end{array}$} & \multicolumn{2}{|c|}{$\begin{array}{l}\text { Private } \\
\text { nursing } \\
\text { home }\end{array}$} & \multirow{2}{*}{$\begin{array}{l}\text { Misc. } \\
\text { (men) }\end{array}$} & \multirow[t]{2}{*}{ Total } \\
\hline & $\overline{\text { Men }}$ & Women & Men & Women & $\overline{\text { Men }}$ & Women & Men & Women & & \\
\hline 1970 & 4 & 2 & 2 & I & & 3 & & & & I2 \\
\hline I97I & I & I & 3 & 2 & 3 & 4 & & & 2 & I6 \\
\hline I972 & 2 & 2 & & & 3 & I & & & & 8 \\
\hline I973 & 4 & I & & & 2 & & & & I & 8 \\
\hline I974 & 5 & & I & & 4 & & & & I & I I \\
\hline I975 & 5 & I & & I & 2 & & & I & & IO \\
\hline Total & $12 \mathrm{I}$ & 7 & 6 & 4 & I4 & 8 & & I & 4 & 65 \\
\hline
\end{tabular}

TABLE V

Experience of sixty-five tetraplegics in institutions

\begin{tabular}{|c|c|c|c|c|c|c|c|}
\hline \multirow[t]{2}{*}{ Year } & \multicolumn{2}{|c|}{ Died in home } & \multicolumn{2}{|c|}{$\begin{array}{l}\text { Returned to } \\
\text { community } \\
\end{array}$} & \multicolumn{2}{|c|}{ Still in home } & \multirow[t]{2}{*}{ Total } \\
\hline & Men & Women & Men & Women & Men & Women & \\
\hline I970 & 4 & 2 & I & I & I & 3 & 12 \\
\hline I97I & 4 & 2 & 3 & & 2 & 5 & I6 \\
\hline I972 & & & & & 5 & 3 & 8 \\
\hline I973 & 4 & & & I & 3 & & 8 \\
\hline I974 & I & & 2 & & 8 & & I I \\
\hline I975 & & & 2 & & 5 & 3 & IO \\
\hline Total & I3 & 4 & 8 & 2 & 24 & I4 & 65 \\
\hline
\end{tabular}




\section{I97I}

The lady languishes in a statutory young disabled unit. Although she now has compensation, she is apparently so institutionalised after 6 years that she cannot make the effort to escape. The man wisely married a nurse after 4 years and was able to leave what he described as a prison. Of the five in geriatric wards, all three men died within 6 months of discharge from Stoke Mandeville. The two ladies survive. One man and two women in voluntary homes have also died. Under miscellaneous this includes one man and his family who accepted bungalow accommodation within a Cheshire Home complex and the other went into a hostel for a temporary period because of family relationships breaking down.

\section{2}

All eight are alive. Two young men out of this number were admitted from home following domestic difficulties.

\section{3}

Two of the men in statutory homes have died. The lady left after 3 years and is now living with parents. Both men in voluntary homes are dead, one of them having been admitted from home following domestic disasters. Under miscellaneous is a man and his family who accepted a place in a Cheshire Home bungalow some time after discharge home.

\section{4}

All five in the young disabled units are alive. Indeed, two of them very much so; one just married to a nurse, the other about to be, and both will be living out in the community. As for the man in the geriatric unit, he died only I month after admission.

1975

At the time of writing this paper, all ten are alive and two of these have returned to the community.

\section{Results}

Out of the total number of $65, \mathrm{I} 7$ were found to be deceased and ten subsequently returned to the community, leaving me with 38 patients in the residential setting for consideration. I have been able to visit, personally, 22 of the patients and thus had the opportunity of seeing a cross-section of residential establishments and of staff and the care offered. The remaining 26 , which included the ten who left their establishments, have corresponded or spoken with me and answered my questions very frankly and in great detail.

This follow-up has revealed very clearly the problems facing: $(a)$ the medical social worker who places the patient; $(b)$ the patient who has to accept residential care; and $(c)$ the staff who care for them.

What is the medical social worker looking for ? She hopes to find: (I) accommodation where there will be skilled medical and nursing care; (2) a positive approach on the part of staff to assess a patient's capabilities and to offer appropriate facilities to help fulfil intellectual and emotional needs; and (3) an attractive environment where a patient may enjoy a family atmosphere or privacy or both, according to his requirements.

From the patient's point of view, it is unfortunate that too often discharge from hospital from the medical angle, does not coincide with his social needs. 
It therefore happens that a patient may be placed in residential care almost totally unprepared, and he may have an unrealistic or euphoric idea of what the establisment has to offer. It is also very difficult for a patient to retain his individuality in an institution as the staff, albeit unintentionally, may place him in a humiliating or subservient role.

Because staff in a residential setting provide all aspects of physical care they may have great difficulty in remaining objective and un-involved with patients. They may actually enjoy the situation where a patient is dependent upon them and encourage them to be so. They may also feel frustrated because their particular institution has so little to offer. The staff also complained to me of demanding patients who were extremely selfish and self-centered. The patient/staff relationship should consist of a mutual acceptance of one anothers' needs which is a most difficult balance to accomplish.

There seem to be seven points which are of primary importance in determining acceptance of residential care: the reason for admission and therefore the attitude of the patient; personality, age and sex; nursing and medical care; environment and facilities within the home; respect for and an ackowledgement of the individual's right to live his life as normally as possible; sexual relationships where required; reaction of family and friends to residents and staff. In elaborating the points above I have included the personal views of a number of tetraplegics.

The reasons for the original 65 being placed in residential care are shown in Table VI. Nine out of the ten who were admitted to residential care because of unsuitable, or no accommodation, returned subsequently to the community. Of these I quote three: 'My sanity would have deserted me had I not been aiming to live out in the world again.' 'I only kept going because I knew that eventually I would get out.' 'I virtually detested every moment. I found the experience akin to being a specimen in the zoological gardens.' The other end of the scale is summed up by, 'I enjoy a happy and contented existence due to a devoted and hard-working staff who try to make life as normal as possible in such circumstances'. The one male patient who elected to go into long-term care because he felt he would be a burden to his parents is very philosophical and says, 'I can do my own thing at Le Court Cheshire Home and I think I have the best possible world in my situation'.

Those patients with placid or indolent personalities and with little academic ability seem to find institutional life easier to bear and, on the whole, women have shown a greater tolerance than men. Twenty-six per cent of men who went into long-term care and survived, have returned to the community, whereas only I3 per cent of the women have done so. The age range is between $17-65$, and

TABLE VI

\begin{tabular}{|c|c|c|c|c|c|c|}
\hline & $\begin{array}{c}\text { No } \\
\text { accommoda- } \\
\text { tion }\end{array}$ & $\begin{array}{c}\text { Divorce, } \\
\text { broken } \\
\text { engagement }\end{array}$ & $\begin{array}{l}\text { Family } \\
\text { unable } \\
\text { to cope }\end{array}$ & $\begin{array}{c}\text { No } \\
\text { family }\end{array}$ & $\begin{array}{l}\text { Chose } \\
\text { long-term } \\
\text { care }\end{array}$ & Total \\
\hline$M$ & 8 & 6 & 27 & 2 & I & 44 \\
\hline $\begin{array}{l}\mathrm{F} \\
\mathrm{C}\end{array}$ & 2 & 5 & $\begin{array}{r}\text { IO } \\
\text { I }\end{array}$ & 3 & & $\begin{array}{r}20 \\
I\end{array}$ \\
\hline Total & IO & I I & 38 & 5 & I & 65 \\
\hline
\end{tabular}


mostly in the upper bracket and this for the young tetraplegic is yet another problem.

Although some medical and nursing staff have had little experience of patients with spinal cord injury, they have I understand, been willing to learn and, almost without exception, there has been praise for the care received.

Homes, both statutory and voluntary, have mostly single rooms where residents can enjoy a fair degree of privacy-some even have their own shower and loo attached. The majority of buildings are attractive and functional. Some are very go-ahead and have well equipped workshops and training schemes. Facilities for occupation on the whole, however, are sadly lacking and boredom seems to be the chief enemy.

The attitude of staff towards the residents varies from place to place and there is no pattern. Some patients talk of dedicated and compassionate staff but two at least have complained of the matrons as 'dictators' and that subtle revenge and persecution have followed when a resident has voiced an unwelcome opinion. One man quotes: 'Staff tend to treat rational, intelligent, mature patients with a condescension reserved for remedial juvenile delinquents who will be recidivists unless kept firmly under control'. Nearly all have agreed that shortage of staff creates irritability and tension, and that too often decisions are made for residents without consulting them. As one man said, 'I think they would prefer me to be a conforming cabbage'. However, the main bone of contention is over residents with disabilities other than spinal cord injury. Only very few tetraplegics seem to be able to identify with the people behind the often grotesque or deformed bodies of other residents and for the most part, they find the unfortunate sufferers of progressive diseases depressing and distressing and they appear to be unable or unwilling to communicate with them. They have been condemned by some staff as being almost wholly intolerant and indifferent to other people and one matron remarked, 'tetraplegics seem to think they are the cream'.

There were many comments on the subject of sexual relationships: 'Opportunity would be a fine thing.' 'After much hilarious discussion it was agreed that I could have a lock on my door for a trial period.' 'Being semi-locked away from society it is well nigh impossible to form a close relationship with the opposite sex.' Nevertheless, as already stated, several of the tetraplegics followed up have by now married or are just about to.

There may be a difficult period when a patient first goes into residential care. $\mathrm{He}$ is apprehensive and may appear depressed. Well-meaning relatives or friends who stir up their emotions would be well advised to let the patient have an opportunity of settling. For example, recently, a well-meaning lady, ignorant of the true facts of a particular case and believing the patient to be unhappy, suggested that she would find him an alternative establishment. His father now writes, 'After his initial despondency he likes his situation very well and seems to be the apple of everybody's eye. They spoil him and allow him complete licence to do exactly what he likes and from his point of view, he has the life of a lord.'

\section{Conclusion}

From what the patients have told me and from my own impressions I have formed the conclusion that some of the criticism projected against residential care is warranted although in some cases there has been prejudice. I find that the answers to my two original questions are: (I) Almost without exception residential establishments do not have clear objectives except to give adequate physical care. 
(2) Tetraplegics appear to want, above all things, to live with others of similar disabilities and age groups.

What is needed to improve standards? I would like to suggest the following: (I) Time in which to prepare and educate a patient for care in the residential setting and a much greater involvement of the patient and his family in the steps leading up to admission. (2) Much more information about the home, its aims, facilities and care available. (3) Close liaison and detailed reports from the hospital team to the staff of the selected home. (4) Involvement of the residents in the running of the establishment and more recognition of their rights as individuals. (5) Scope and encouragement to use known skills or learn new ones both inside and outside the institution and the opportunity to earn money where possible. The importance of a degree of financial independence should not be overlooked. (6) The ultimate goal, where feasible, of resettlement in the community.

I believe that it would be possible to implement some of these items but more important still is the need to recognise that tetraplegics in residential care have the right to the same quality of life as those who are more fortunately able to live at home.

\section{SUMMARY}

The follow-up of 65 cases in residential care has shown that there was an early mortality rate where the level of lesion was $\mathrm{C}_{5}$ or above. It appeared that there was little difference in the attitude of male and female tetraplegics of any age group towords tolerance of residential care. The degree of acceptance was found to be related to the facilities offered, the involvement of the patient in the running of the establishment and the disabilities suffered by other residents. The study has shown that patients are not sufficiently prepared for long-term residential care; that the institutions and their staff usually have no specific aims and that tetraplegics would prefer to live amongst others with a similar handicap.

\section{RÉSUMÉ}

Ce révue des soixante cinque Tétraplégiques en bon soin des Résidences pour les handicappés, a montré qu'il avait un mortalité précoce entre les Tétraplégiques avec un lesion au dessus de $\mathrm{C}_{5}$. Il parait qu'il avait peu de différence en attitude des Tétraplégiques, masculin ou feminine n'importe quel âge, d'accepter les bons soins des Maisons de Résidences. Le degré d'acceptance était trouvés plutôt en repport des facilités existant, l'involvement des Handicappés avec la conduite de ces Residences, et les incapacités differentes des autres Résidents.

Cet évaluation a montré que les Tétraplégiques n'était pas suffisament préparer à accepter les bon soins de ces résidences comme une solution pérmanente. Les Résidences et leur Personel en générale n'ont pas de but spécifique et les Tétraplégiques prefereraient vivre avec des autres malades de même handicap.

\section{ZUSAMMENFASSUNG}

Die Nachkontrolle von 65 Heiminsassen zeigte eine frühe Mortilitätsrate für Tetraplegiker mit Läsionshöhe $\mathrm{C}_{5}$ oder höher. Scheinbar besteht zwischen Männern und Frauen aller Altersgruppen wenig Unterschied in der Einstellung zur Heimpflege. Wie weit die Situation als solche akzeptiert wird, hängt weitgehend davon ab, was für Möglichkeiten den Inassen offeriert werden, inwieweit die Insassen in die Organisation des Heims einbezogen warden und was für Behinderungen die Mitinsassen aufweisen. Unsere Studie zeigt, dass die Patienten ungenügend auf einen Langzeitaufentalt in einem Heim 
veorbereitet werden, ferner dass üblicherweise Institutionen und Personal kein spezielles Ziel anstreben und dass Tetraplegiker es vorziehen, mit Insassen gleicher Behinderung zussammenzuleben.

Acknowledgements. I would like to thank all those patients and staff who have cooperated so fully, which made this paper possible. 